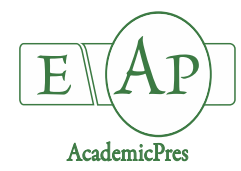

Koochani M et al. (2020)
Notulae Botanicae Horti Agrobotanici Cluj-Napoca 48(4):1915-1928
DOI:10.15835/48411669
Research Article

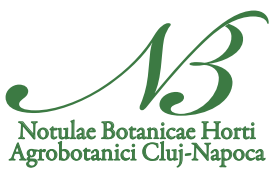

\title{
A comparative study on the effects of ultrasound and some growth factors on somatic embryogenesis and artificial seed production in cucumber (Cucumis sativus L.)
}

\section{Morvarid KOOCHANI ${ }^{1}$, Ahmad MAJD ${ }^{1 *}$, Sedigheh ARBABIAN ${ }^{1}$, Faezeh GHANATI ${ }^{2}$, Sayeh JAFARI MARANDI ${ }^{1}$}

\author{
${ }^{1}$ Islamic Azad University, North Tehran Branch, Faculty of Biological Sciences, Department of Biology, 10th Bostan St., Southern \\ MakranSt., HeraviSq., Tehran, Iran; morvaridkoochani@gmail.com; ahmadmajd537@gmail.com (*corresponding author); \\ arbabias@gmail.com; jafarisayeh@gmail.com \\ ${ }^{2}$ Tarbiat Modares University (TMU), Faculty of Biological Sciences, Department of Plant Biology, No.7, Jalal AleAhmad St., Tehran, \\ Iran; ghangia@modares.ac.ir
}

\begin{abstract}
Cucumber (Cucumis sativus L.), a popular vegetable crop of the family Cucurbitaceae, is cultivated in different parts of the world and is of great economic importance. Ultrasound is known as a physical stimulus that can affect living systems. At the right frequency and exposure period, these waves have desired effects. In the present study, 2-week-old plants, were put in an ultrasonic bath with a nominal frequency of $40 \mathrm{kHz}$, a central frequency of $34 / 722 \mathrm{kHz}$ and a bandwidth of $320 \mathrm{~Hz}$ for $0,5,10$ and 15 minutes. Hypocotyl pieces were used as explants and cultured in Murashige and Skoog medium supplemented with 0/5 mg/l each of 2,4dichlorophenoxyacetic acid, 1-Naphthalene acetic acid, kinetin and 6-benzylaminopurine. The use of ultrasonication at a nominal frequency of $40 \mathrm{kHz}$ for 10 minutes showed better results as compared with the samples treated for 0,5 and 15 minutes, in terms of the shape, maturity of the embryos, and also the germination of artificial seeds and maturing to flowering stage. Since the cucumber of Esfahan is very famous for its aroma and taste and it is somewhat at risk of extinction, we studied the production of artificial seeds of this valuable plant using somatic embryos and apical buds. This research is the first report on investigation of the positive effect of ultrasound on somatic embryogenesis and artificial seed production. our results clearly showed that this method is a practical method to accelerate seed germination and flowering stage.
\end{abstract}

Keywords: acclimatization; callogenesis; histology; sodium alginate; synthetic seeds

\section{Introduction}

Cucumber (Cucumis sativus L.), is one of the most important and widely used vegetables in the world, which has a special position and popularity (Hassanein, 2003). It purifies the blood and has chemical compounds effective in treating cancer and is consumed in poisoning and digestive disorders (Ugandhar et al., 2011). It also cools the body and helps digestion (Passalacqua et al., 2007). Ultrasound is a physical stimulus, 
affecting living systems, depending on the type of cell and its response to these physical stimulations on one side, and to the energy of these waves on the other side (Liu et al., 2003).

Recently, much attention has been devoted to the beneficial effects and potential applications of lowenergy ultrasound in biological systems and biotechnological processes, especially for food quality control, as a non-destructive method (Rajewska and Mierzwa, 2017). The use of these high-energy waves can have destructive effects, including destruction of cell membranes and important biochemical molecules such as enzymes and DNA (Chen et al., 2008). However, low-intensity waves can have beneficial effects on these systems (Da Silva and Dobránszki, 2014).

These waves are categorized into two groups based on frequency domain:

1-Low intensity and energy waves (between 20 and $100 \mathrm{kHz}$ )

2-High intensity and energy waves (more than $100 \mathrm{kHz}$ ) (Nowacka and Wedzik, 2016).

Ultrasound can be very effective in stimulating seed germination, increasing germination percentage, and accelerating plant growth (Yang et al., 2015).

In plant cell tissue culture systems, the increased cell and callus growth is also reported in some plants like Corylus avellana, Oryza sativa and Soybean as influenced by ultrasound ( Liu et al., 2003; Rezaei et al., 2011; Safari et al., 2013; Ghanati et al., 2015; Yang et al., 2015). Plant tissue culture is an important and efficient technique in the field of basic and applied sciences, and also has commercial application (Isah, 2015).

This phenomenon is due to the thought and idea of a German scientist, Haberlandt, at the beginning of the 20th century. He stated that cultured plant cells were capable of growing, dividing, and transforming into complete plants. He is known as the father of plant tissue culture (Bhatia and Dahiya, 2015).

Reducing the number of generations, shortening the time for improvement of woody and herbaceous plants, and the extraction of pharmaceutical and chemical substances and various essential oils, as well as the propagation of species that cannot propagate within the soil, are among the other uses and benefits of plant tissue culture (Vasil, 2008).

Somatic embryogenesis is an artificial process in which, a plant or embryo is derived from a single somatic cell and have the potential to produce a large number of seedlings (Juturu et al., 2015). In most cases, somatic embryos have the ability to be stored, providing the possibility of creating a gene bank for plants (Sunandar and Supena, 2017).

In order to effectively regulate the formation of plants through somatic embryogenesis, it is important to understand how the somatic embryos evolve and how this evolution is influenced by physical and chemical treatments (Von Arnold et al., 2002). The controlling mechanisms of cell differentiation during somatic embryogenesis is not entirely clear and there are still a lot of unknowns about it (Thorpe, 2007). Potentially, somatic embryos have many biotechnology applications, one of which is the production of artificial seeds (Gantait et al., 2015). Artificial seed technology is based on the use of somatic embryos, lateral buds, and apical meristem, creating a method for the production of similar seeds used for micropropagation and cloned seedlings in the future (Dobránszki and da Silva, 2010).

Growth regulator factors are the synthetic form of hormones in the artificial conditions, whose type and concentration vary depending on the purpose of the culture. There is a belief that, the in vitro plant tissue culture without growth regulators is almost impossible to achieve (George, 1993).

In cucumber, 2,4-dichlorofenoxy acetic acid is the most common form of auxin to induce callogenesis, somatic embryogenesis and its growth, used either independently or in combination with NAA. NAA is also used as an auxin for callogenesis and callus growth, acts similar to 2,4-D but it is less used compared to 2,4-D. Cytokinins are the other plant growth regulators (Kn, BA), accelerating cell division (Cade et al., 1990). The presence of auxin and cytokinin together can have a positive effect on the induction of callogenesis and the subsequent development of embryonic calli (Tripathi and Tripathi, 2003). A suitable osmotic pressure in culture media is one of the effective factors in the growth of callus and embryogenesis in plants. This osmotic pressure could be provided by disaccharides such as sucrose, which is often used as an organic carbon source in the culture medium (Lou and Kako, 1995). 
Since the cucumber of 'Esfahan' is very famous for its aroma and taste and it is somewhat at risk of extinction, we studied the production of artificial seeds of it. The purpose of this study was to prove the positive effects of ultrasound and growth regulators on optimization of tissue culture in order to produce embryonic calli and produce artificial seeds through both somatic embryogenesis and apical buds of this valuable plant. This research is the first report on the investigation of the positive effect of ultrasound on somatic embryogenesis and artificial seed production.

\section{Materials and Methods}

\section{Callogenesis}

The seeds of cucumber (Cucumis sativus cv. 'Dastgerd Esfahan') were purchased from Esfahan Pakan Bazr Company. After homogenizing the seeds in order to sterilize them under the laminar hood, the seeds were first washed in $5 \%(\mathrm{~V} / \mathrm{V})$ sodium hypochlorite for 5 minutes and then washed with sterile double distilled water 3 times, each time for 5 minutes. Then, the seeds were washed in $70 \%(\mathrm{~V} / \mathrm{V})$ ethanol for 1 minute and again washed with sterile double distilled water 3 times each time for 5 minutes. In order to dry the seeds, filter papers, sterilized by autoclave $\left(121^{\circ} \mathrm{C}\right)$, were used. After drying the seeds, they were cultured on the MS medium (Murashige and Skoog, 1962) without growth regulators under a photoperiod of 16 hours light/8 hours' dark at culture room temperature $\left(22 \pm 2{ }^{\circ} \mathrm{C}\right)$. The $\mathrm{pH}$ of the medium was adjusted to 5.8 with $0 / 1 \mathrm{M}$ $\mathrm{NaOH}$ or $0 / 1 \mathrm{M} \mathrm{HCl}$ before adding $0.8 \%(\mathrm{M} / \mathrm{V})$ agar and autoclaved at $121^{\circ} \mathrm{C}$ for 15 minutes. After four days, the seeds germinated and, after two weeks, turned into seedlings in sterile conditions. The 2-week-old seedlings were put in an ultrasonic bath (Falc Instruments, Treviglio, Italy) with a nominal frequency of 40 $\mathrm{kHz}$, a central frequency of $34.722 \mathrm{kHz}$ and a bandwidth of $320 \mathrm{~Hz}$ (Rezaei et al., 2011) for 0, 5, 10 and 15 minutes. Then, hypocotyl pieces $(6 \mathrm{~mm}$ in size) were used as explants. The explants were placed in Murashige and Skoog medium (Murashige and Skoog, 1962) including M1 medium: supplemented with 0/5 mg/l each of 2,4-dichlorophenoxyacetic acid (2,4-D), 1-Naphthalene acetic acid (NAA) and Kinetin (Kn) and M2 medium : supplemented with $0 / 5 \mathrm{mg} / \mathrm{l}$ each of 2,4-dichlorophenoxyacetic acid (2,4-D), 1-Naphthalene acetic acid (NAA) and 6-Benzylaminopurine (BA) in dark conditions for induction of embryogenesis.

\section{Embryogenesis}

Embryogenesis started after six weeks and calli with globular embryos formed. After four weeks, the samples were transferred to MS medium, containing $40 \mathrm{~g}$ of sucrose per litre as the first subculture and for the formation of heart-shaped embryos. One month later, the samples were transferred to the MS medium, containing $50 \mathrm{~g}$ of sucrose per litre as the second subculture for the formation of torpedo-shaped embryos. After stereomicroscopic observation (BEL-STMPRO-B), appropriate samples were photographed by CanonPowerShot SX230.

\section{Histology of embryos}

To ensure embryogenesis, the microtome cuts were prepared from calli, so that samples were fixed in a FAA fixative (formalin, glacial acetic acid, 70\% ethanol- 5:5:90) for three and half hours. Samples were then dehydrated in increasing degrees of ethanol and saturated with toluene and paraffin. Paraffin-embedded specimens were sectioned. Serial sections (8-10 mm thick) were made using a microtome (CUT-4060, SLEE) fitted with a steel knife. Then stained by haematoxylin and eosin after removing paraffin and ethanol dehydration. After microscopic observation (Nikon-Eclipse-E200), appropriate samples were photographed by Canon- power Shot SX230. 


\section{Artificial seeds production}

For the production of artificial seeds, $2 \mathrm{~g}$ of Sodium alginate powder was solved in $100 \mathrm{ml}$ of MS medium $(2 \% \mathrm{~W} / \mathrm{V})$. Then, mature somatic embryos at the torpedo stage and apical buds were separated by scalpel under stereomicroscopic (BEL-STMPRO-B) under the laminar hood, along with sodium alginate dropped in to 100 $\mathrm{mM} \mathrm{CaCl} 2.2 \mathrm{H} 2 \mathrm{O}$ solution and shaken slowly in order to encapsulate the whole embryo and bead formation. The beads were washed in sterile double distilled water and after drying on sterilized filter paper to remove excess water, they were transferred to the PGR-free MS medium. Synthetic seeds incubated at $22 \pm 2{ }^{\circ} \mathrm{C}$ with a 16-h photoperiod for germination. All these processes were done under the laminar air flow chamber in order to avoid microbial contamination (Cheruvathur et al., 2013).

\section{Acclimatization}

After germination and seedling formation, the samples were transferred to the sterile Perlite soil and covered with a lid. Irrigation was done with Hoagland solution in the first week. By piercing the lid and then gradually removing it (acclimatization phase), the samples were transferred to garden soil and kept in the greenhouse environment to observe their growth and flowering stage. The plantlets were watered every day.

\section{Statistical analysis}

Each treatment consists of six Petri dishes each containing five samples $(\mathrm{n}=30)$. All experiments were performed in a completely randomized design with at least three replications. Statistically significant differences were determined by analysis of variance (ANOVA) and the Duncan multiple range test (DMRT) at a $\mathrm{p} \leq 0.05$ level of significance (Duncan, 1955). Data obtained from all experiments were presented as the mean $\pm S E$ of three replications.

\section{Results}

The callogenesis started after four weeks of culture of the explants in M1 and M2 media (Figure 1). Two weeks after the formation of calli, embryoid mass cells and globular embryos appeared. Globular embryos differentiated into heart-shaped ones by the first subculture of samples in the MS medium with $40 \mathrm{~g}$ of sucrose per litre. In the second subculture, heart-shaped embryos were transferred to basic culture medium, containing $50 \mathrm{~g}$ of sucrose per litre and after one month, heart-shaped embryos differentiated into the torpedo-shaped ones.

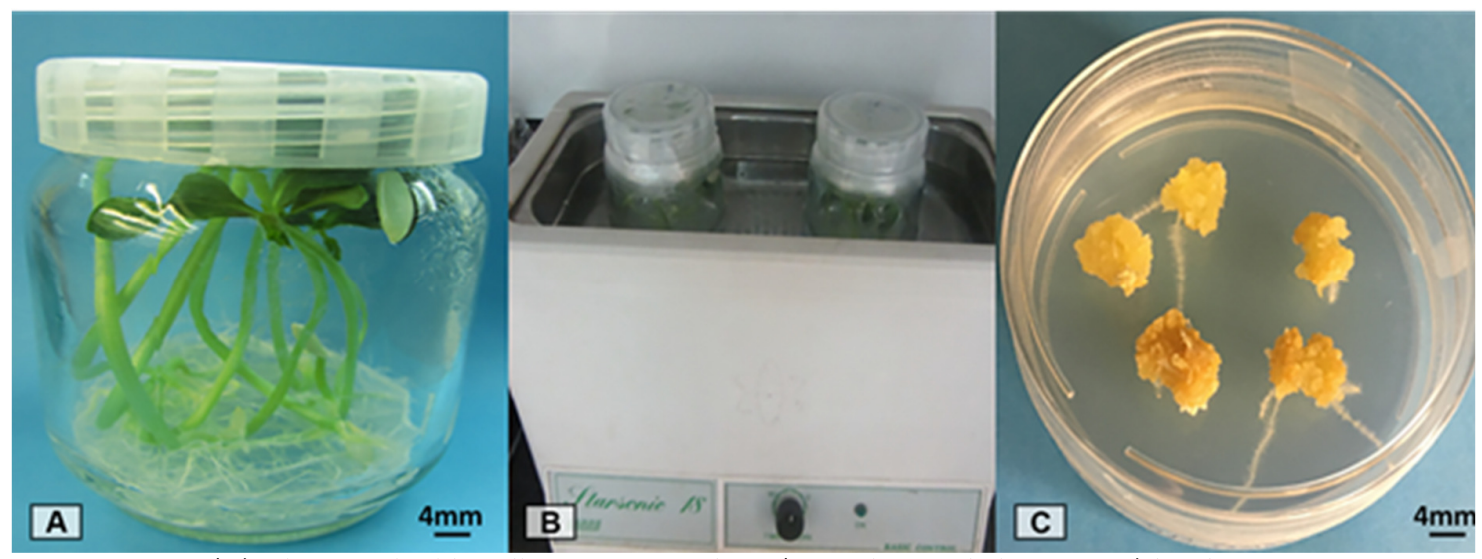

Figure 1. (A) The 2-week-old seedlings in MS medium (Murashige and Skoog, 1962) by objective $0.2 \mathrm{X}$, (B) The 2-week-old seedlings were put in an ultrasonic bath, (C) Embryonic calli of cucumber obtained from hypocotyl by objective $0.7 \mathrm{X}$ 
To ensure embryogenesis, microtome sections were prepared and stained from embryonic calli, as described in the materials and methods. In the sections, the stages of embryos formation and development were observed, so that globular embryos were formed from embryonic callus cells and connected to cells underneath by suspensor cells (Figure 2).
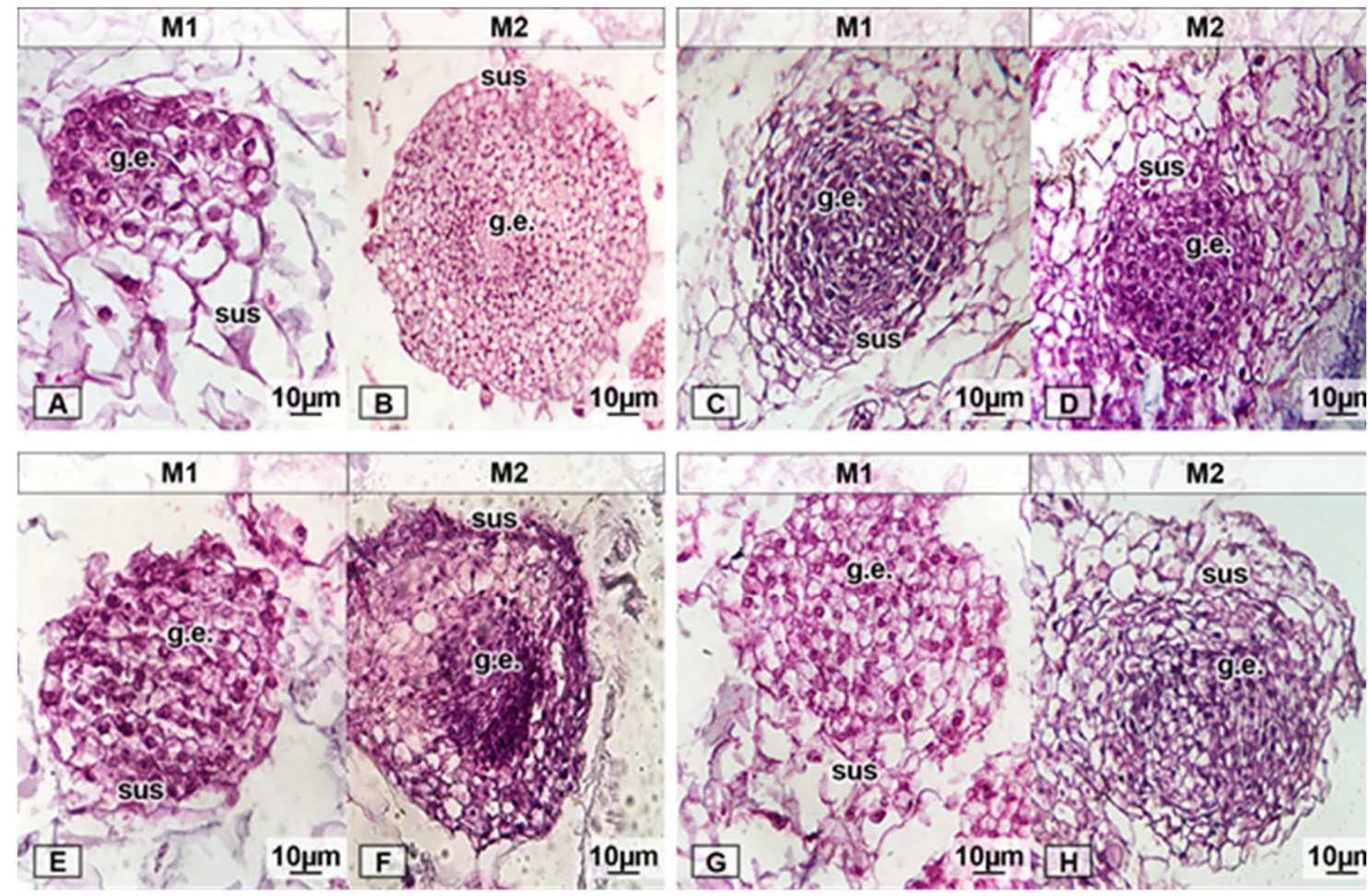

Figure 2. Microtome sections of embryonic callus and globular embryos stages derived from cucumber hypocotyl explants in Murashige and Skoog medium (Murashige and Skoog, 1962), containing 0/5 mg/l each of 2,4-D, NAA and $\mathrm{Kn}$ as M1 medium and containing $0 / 5 \mathrm{mg} / \mathrm{l}$ each of 2,4-D, NAA and BA as M2 medium. By objective $40 \mathrm{X}$ [g.e: globular embryo; sus: suspensor]. (A) Control sample in M1, (B) control sample in M2, (C) 5-minutes treatment in M1, (D) 5-minutes treatment in M2, (E) 10-minutes treatment in $\mathrm{M} 1,(\mathrm{~F})$ 10-minutes treatment in $\mathrm{M} 2,(\mathrm{G})$ 15-minutes treatment in $\mathrm{M} 1,(\mathrm{H})$ 15-minutes treatment in M2

In the next stage, the cell division began at both embryo poles; globular embryos moved towards bipolarization and cotyledons began to form on their sides (Figure 3).

In the next stage, the cotyledons grew more, moving towards torpedo-shaped embryos and when these divisions increased at both embryo poles, mature cotyledon embryos were formed, in which the cotyledons were thoroughly grown (Figure 4). 

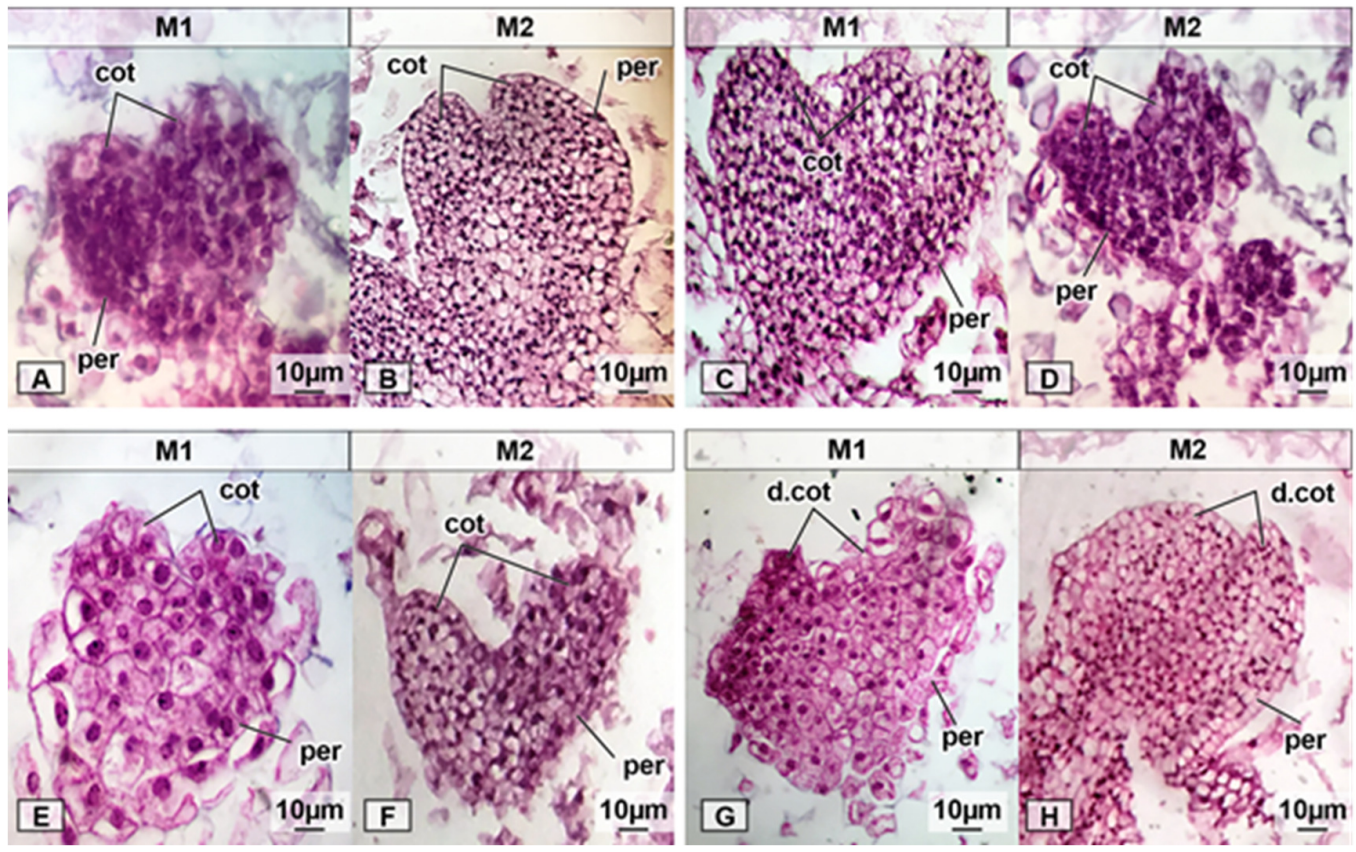

Figure 3. Microtome sections of embryonic callus and heart-shaped embryos stages derived from cucumber hypocotyl explants in Murashige and Skoog medium (Murashige and Skoog, 1962), containing 40g sucrose per liter by objective $40 \mathrm{X}$ (cot: cotyledon; $\mathrm{d}$. cot: deformed cotyledon; per.: periderm). (A) Control sample in M1, (B) control sample in M2, (C) 5-minutes treatment in M1, (D) 5-minutes treatment in M2, (E) 10-minutes treatment in M1, (F) 10-minutes treatment in M2, (G) 15-minutes treatment in M1, (H) 15minutes treatment in M2
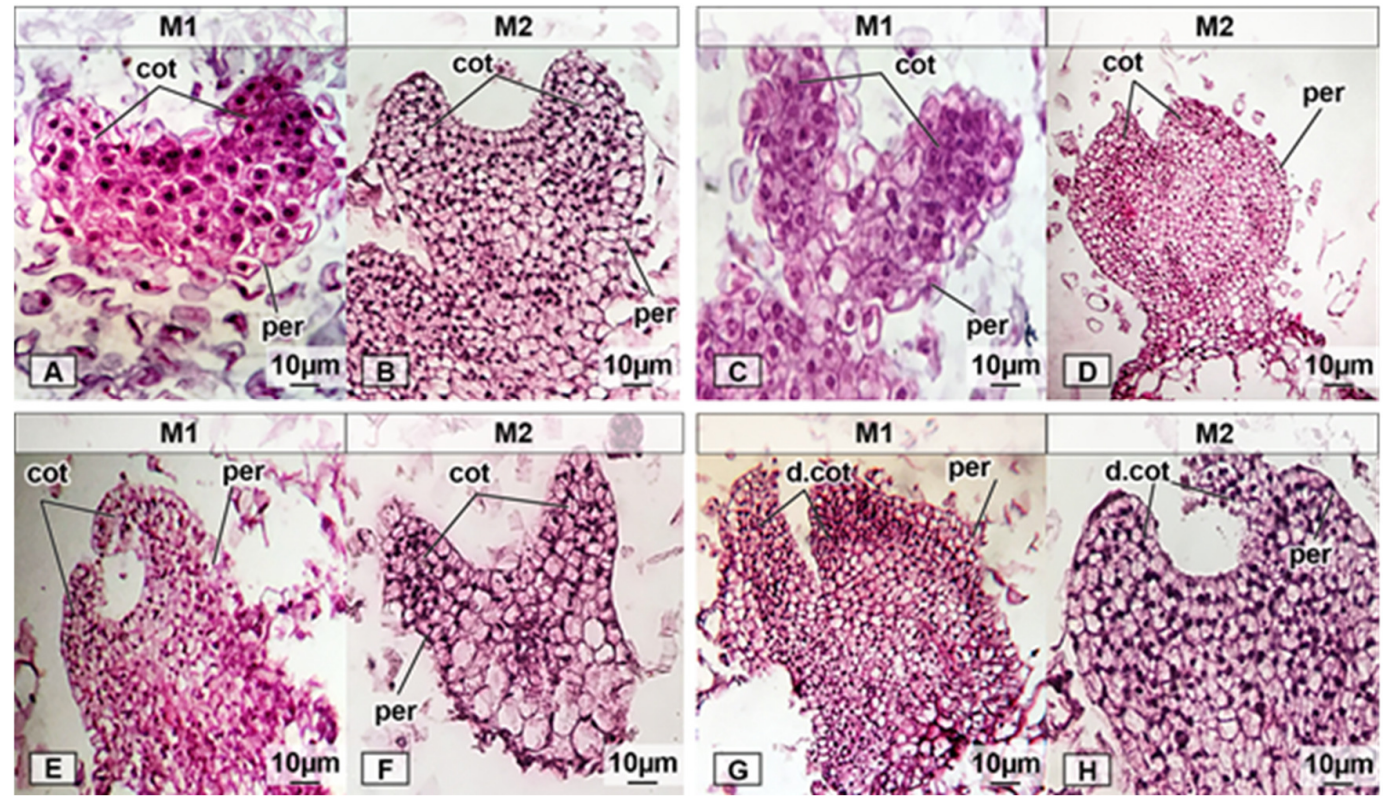

Figure 4. Microtome sections of embryonic callus and torpedo-shaped embryos stages derived from cucumber hypocotyl explants in Murashige and Skoog medium (Murashige and Skoog, 1962), containing $50 \mathrm{~g}$ sucrose per liter by objective $40 \mathrm{X}$ (cot: cotyledon; d.cot: deformed cotyledon; per.: periderm). (A) Control sample in M1, (B) control sample in M2, (C) 5-minutes treatment in M1, (D) 5-minutes treatment in M2, (E) 10-minutes treatment in M1, (F) 10-minutes treatment in M2, (G) 15-minutes treatment in $\mathrm{M} 1,(\mathrm{H}) 15$-minutes treatment in $\mathrm{M} 2$ 
Our results showed the important role of growth regulators including 2,4-D as an auxin, and BA as a cytokinin compared to $\mathrm{Kn}$, which is one of the most important factors in the formation of callus and embryogenesis. The highest percentage of callogenesis was observed in M2 media, in which BA was used, while in M1 medium, Kn was used as cytokinin. The highest percentage of embryo formation was observed in M2 medium in comparison with M1. Similarly, according to the results of artificial seed germination, the highest germination percentage was observed in M2 medium compared to M1 (Table 1).

Table 1. Effects of ultrasound exposure period on callus induction, somatic embryogenesis and synthetic seeds production of Cucumis sativus $\mathrm{L}$

\begin{tabular}{|c|c|c|c|c|c|c|c|c|c|c|c|}
\hline \multirow{2}{*}{ 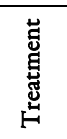 } & \multicolumn{2}{|c|}{ Callogenesis } & \multicolumn{2}{|c|}{ Globular embryo } & \multicolumn{2}{|c|}{$\begin{array}{c}\text { Heart-shaped } \\
\text { embryo }\end{array}$} & \multicolumn{2}{|c|}{$\begin{array}{c}\text { Torpedo-shaped } \\
\text { embryo }\end{array}$} & \multicolumn{2}{|c|}{$\begin{array}{c}\text { Synthetic seeds } \\
\text { from somatic } \\
\text { embryos }\end{array}$} & \multirow{2}{*}{$\begin{array}{l}\text { Synthetic } \\
\text { seeds from } \\
\text { apical buds }\end{array}$} \\
\hline & M1 & M2 & M1 & M2 & M1 & M2 & M1 & M2 & M1 & M2 & \\
\hline $\begin{array}{l}\overline{0} \\
\text { பี } \\
0\end{array}$ & $\begin{array}{l}86.67 \pm \\
6.67 \mathrm{ab}\end{array}$ & $\begin{array}{l}93.33 \pm \\
4.22 \mathrm{ab}\end{array}$ & $\begin{array}{c}88.33 \pm \\
5.27 \mathrm{a}\end{array}$ & $\begin{array}{l}92.50 \pm \\
4.79 \mathrm{~b}\end{array}$ & $\begin{array}{c}75.83 \pm \\
5.33 \mathrm{a}\end{array}$ & $\begin{array}{c}79.44 \pm \\
4.57 \mathrm{a}\end{array}$ & $\begin{array}{c}62.78 \pm \\
7.95 \mathrm{a}\end{array}$ & $\begin{array}{c}65.56 \pm \\
3.89 \mathrm{~b}\end{array}$ & $\begin{array}{l}44.44 \pm \\
15.90 \mathrm{a}\end{array}$ & $\begin{array}{l}55.55 \pm \\
13.37 \mathrm{a}\end{array}$ & $\begin{array}{c}83.33 \pm \\
8.03 \mathrm{a}\end{array}$ \\
\hline 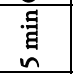 & $\begin{array}{l}73.33 \pm \\
9.89 \mathrm{ab} \\
\end{array}$ & $\begin{array}{c}80 \pm \\
7.30 \mathrm{ab} \\
\end{array}$ & $\begin{array}{c}73.16 \pm \\
6.78 \mathrm{a} \\
\end{array}$ & $\begin{array}{l}76.39 \pm \\
8.17 \mathrm{ab} \\
\end{array}$ & $\begin{array}{l}59.17 \pm \\
14.17 \mathrm{ab}\end{array}$ & $\begin{array}{l}63.33 \pm \\
15.63 \mathrm{a} \\
\end{array}$ & $\begin{array}{l}41.67 \pm \\
15.96 \mathrm{ab}\end{array}$ & $\begin{array}{l}50.28 \pm \\
16.83 \mathrm{ab}\end{array}$ & $\begin{array}{c}25 \pm \\
17.07 \mathrm{ab} \\
\end{array}$ & $\begin{array}{l}47.22 \pm \\
16.34 \mathrm{a} \\
\end{array}$ & $\begin{array}{l}63.33 \pm \\
6.15 \mathrm{ab} \\
\end{array}$ \\
\hline 으 톝 & $\begin{array}{c}96.67 \pm \\
3.33 \mathrm{a} \\
\end{array}$ & $\begin{array}{c}100 \pm \\
0 \mathrm{~b}\end{array}$ & $\begin{array}{c}96.67 \pm \\
3.33 \mathrm{a} \\
\end{array}$ & $\begin{array}{c}100 \pm \\
0 \mathrm{~b}\end{array}$ & $\begin{array}{c}78.33 \pm \\
5.27 \mathrm{a} \\
\end{array}$ & $\begin{array}{l}90 \pm \\
6.83 \mathrm{a} \\
\end{array}$ & $\begin{array}{l}64.72 \pm \\
10.89 \mathrm{a} \\
\end{array}$ & $\begin{array}{c}79.17 \pm \\
5.23 \mathrm{~b} \\
\end{array}$ & $\begin{array}{l}47.22 \pm \\
13.20 \mathrm{a} \\
\end{array}$ & $\begin{array}{c}76.39 \pm \\
8.17 \mathrm{a} \\
\end{array}$ & $\begin{array}{c}86.67 \pm \\
8.43 \mathrm{a} \\
\end{array}$ \\
\hline$\simeq$ : & $\begin{array}{c}60 \pm \\
16.33 \mathrm{~b} \\
\end{array}$ & $\begin{array}{l}63.33 \pm \\
17.45 \mathrm{a} \\
\end{array}$ & $\begin{array}{l}43.33 \pm \\
15.63 \mathrm{~b} \\
\end{array}$ & $\begin{array}{l}56.67 \pm \\
13.82 \mathrm{a} \\
\end{array}$ & $\begin{array}{c}35 \pm \\
17.08 \mathrm{~b} \\
\end{array}$ & $\begin{array}{l}46.67 \pm \\
21.08 \mathrm{a} \\
\end{array}$ & $\begin{array}{c}11.11 \pm \\
7.03 \mathrm{~b} \\
\end{array}$ & $\begin{array}{r}26.39 \pm \\
12.98 \mathrm{a} \\
\end{array}$ & $\begin{array}{l}0 \pm \\
0 \mathrm{~b}\end{array}$ & $\begin{array}{l}0 \pm \\
0 \mathrm{~b}\end{array}$ & $\begin{array}{c}46.67 \pm \\
8.43 b\end{array}$ \\
\hline
\end{tabular}

Note: Mean values within a column with the same alphabet are not statistically significant $(p \leq 0.05)$ according to

Duncan's multiple range test

For the samples treated with ultrasound for 10 minutes, better results were obtained in terms of the shape and maturity of embryos as well as germination of artificial seeds and maturing to plants, compared to those treated for 0,5 , and 15 minutes with these waves. The samples treated for 15 minutes with ultrasound did not have complete embryogenesis, and, as shown in the figures, the embryos were abnormal (Figures 2-4). These waves had a more negative effect on the stages of embryonic maturity, and no germination was observed in the artificial seeds (Figures $5 \mathrm{~g}-\mathrm{h}$ ).
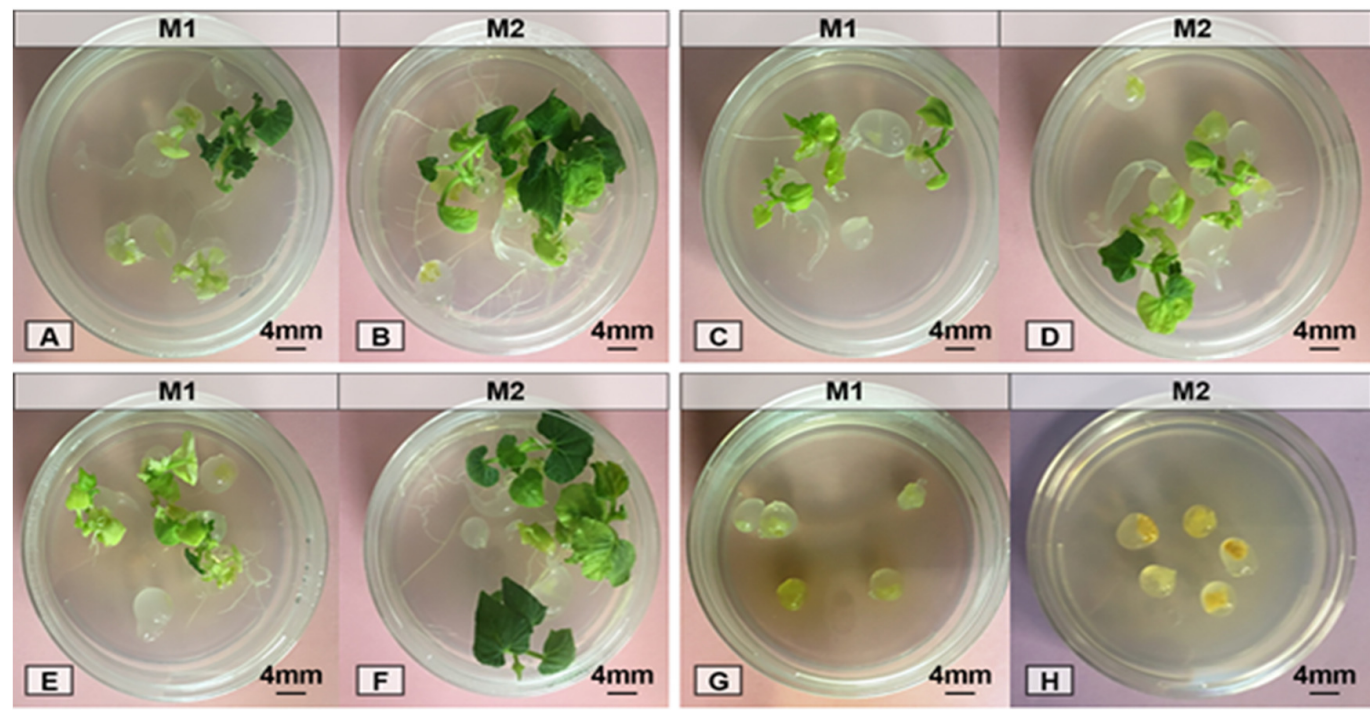

Figure 5. Seed germination of synthetic seeds after four weeks, derived from somatic embryos in Murashige and Skoog medium (Murashige and Skoog, 1962) by objective 0.7 X. (A) Control sample in M1, (B) control sample in M2, (C) 5-minutes treatment in M1, (D) 5-minutes treatment in M2, (E) 10-minutes treatment in M1, (F) 10-minutes treatment in M2, (G) 15-minutes treatment in $\mathrm{M} 1,(\mathrm{H})$ 15-minutes treatment in $\mathrm{M} 2$ 
In the samples treated for five minutes, mature embryos were somewhat observed that retained their shape; however, the results were not remarkable in comparison with the samples treated for 10 minutes, since in comparison with the samples treated for 0 and 10 minutes, less germination was observed and flowering was not observed. The samples treated for 10 minutes had the best response, and ultrasound seemed to have a positive effect on them as compared with the control samples treated for 0 minute (Figures 5-6).

As can be seen in the artificial seeds derived from somatic embryos, the samples treated for 10 minutes, achieved full maturity, including flowering, while the samples treated for 0 minute did not begin the flowering stage (Figure 6).
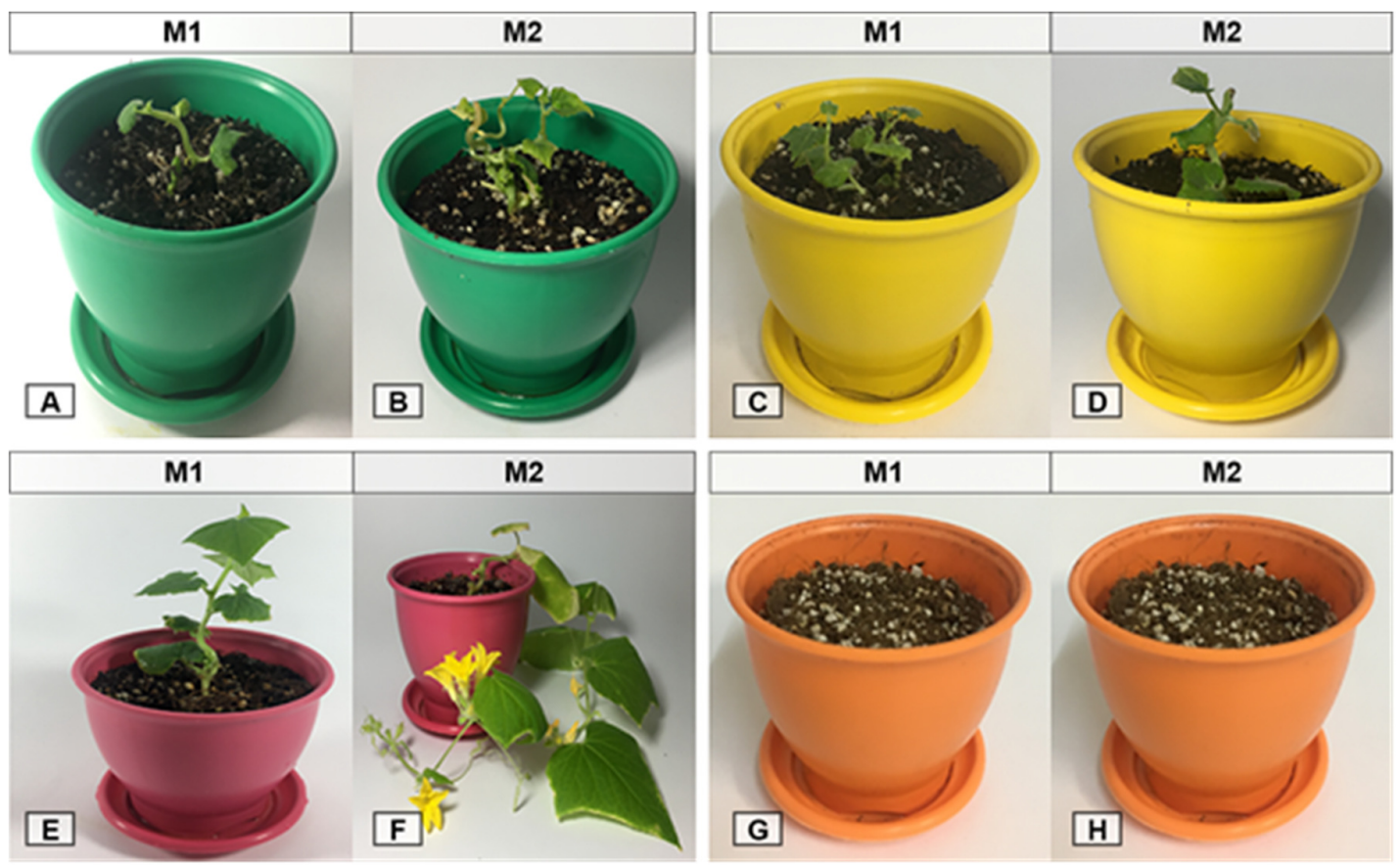

Figure 6. Planting of synthetic seeds in the pot and becoming a plant after six weeks and transferring to the greenhouse environment

(A) Control sample in M1, (B) control sample in M2, (C) 5-minutes treatment in M1, (D) 5-minutes treatment in M2, (E) 10-minutes treatment in M1, (F) 10-minutes treatment in M2, (G) 15-minutes treatment in M1, (H) 15minutes treatment in M2.

The results of artificial seed germination obtained from apical buds showed a significant difference between the samples treated for 15 minutes with those treated for 10 minutes (Figure 7).

The artificial seeds obtained from the samples treated for 10 minutes started the flowering stage faster than the others, and within two weeks. The artificial seeds obtained from the control samples started the flowering stage with a delay of two weeks compared to those treated for 10 minutes. However, the artificial seeds obtained from the samples treated for 5 minutes started the flowering stage very late after eight weeks, and the artificial seeds obtained from the samples treated for 15 minutes did not begin the flowering stage at all (Figure 8). 
Koochani M et al. (2020). Not Bot Horti Agrobo 48(4):1915-1928
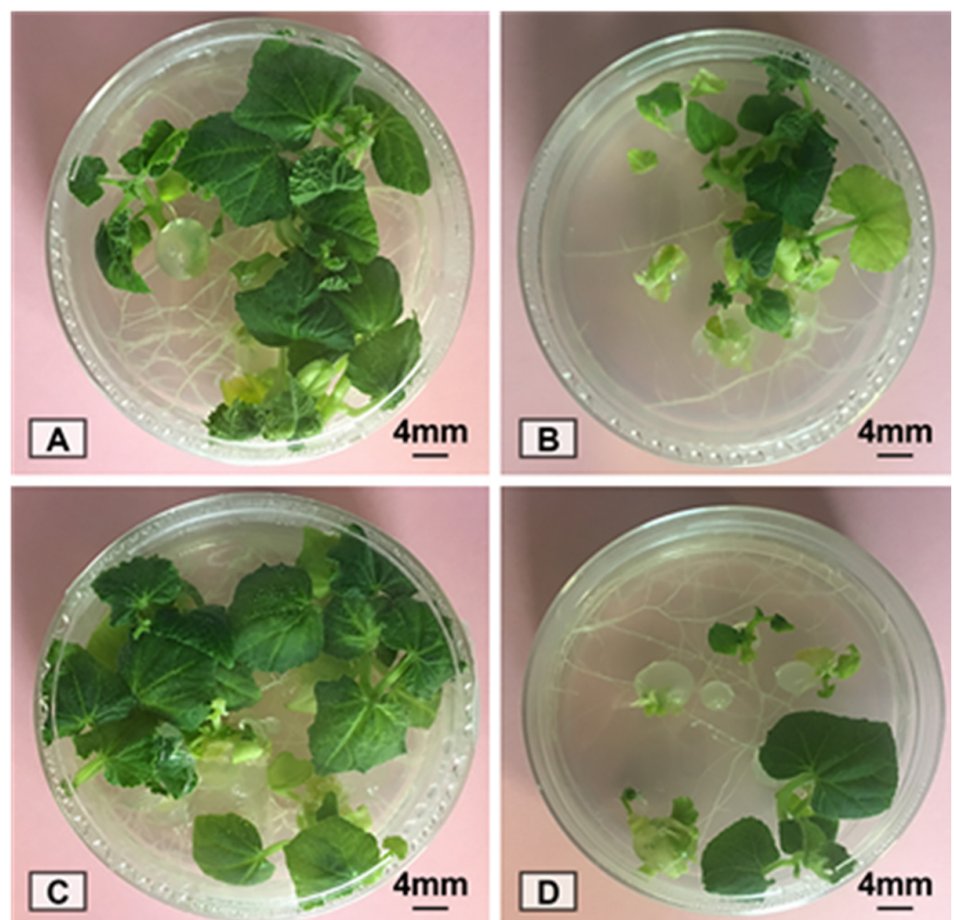

Figure 7. Seed germination of synthetic seeds derived from apical buds in Murashige and Skoog medium (Murashige and Skoog, 1962), by objective $0.7 \mathrm{X}$

(A) Control sample, (B) 5-minutes treatment, (C) 10-minutes treatment, (D) 15-minutes treatment
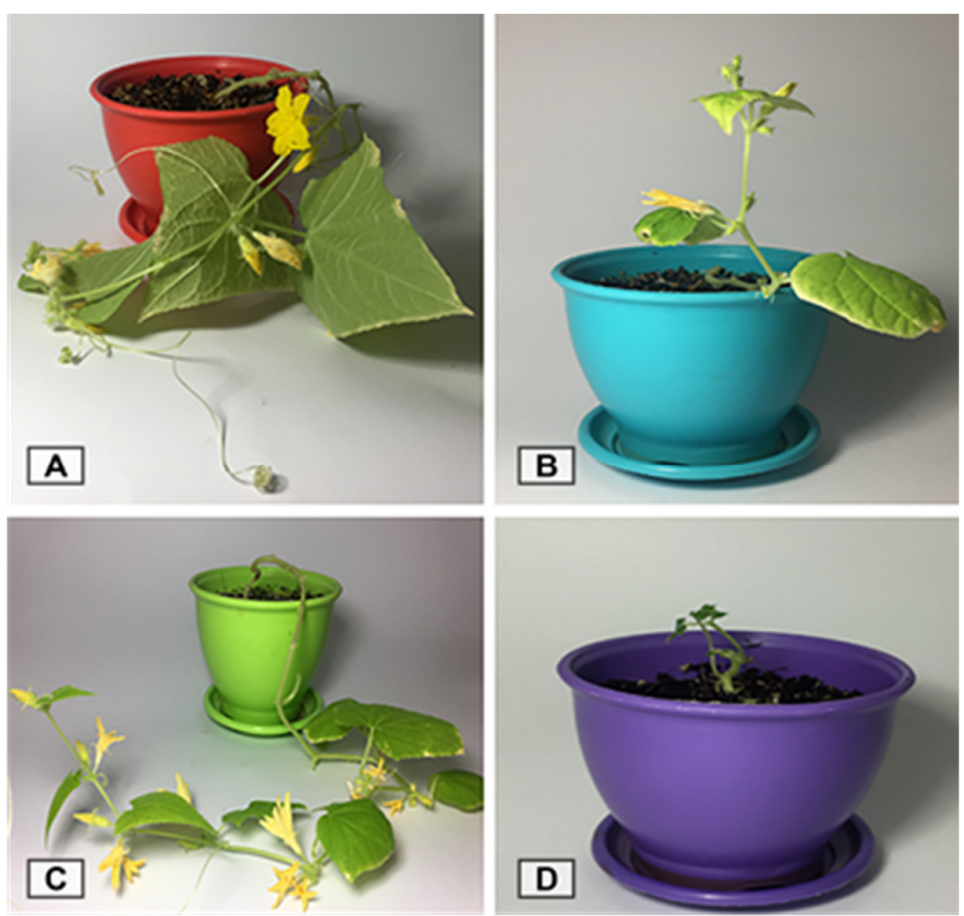

Figure 8. Planting of synthetic seeds derived from apical buds in the pot and becoming a plant after four weeks and transferring to the greenhouse environment

(A) Control sample, (B) 5-minutes treatment, (C) 10-minutes treatment, (D) 15-minutes treatment. 


\section{Discussion}

The results of this study indicate that hypocotyls can be selected as a suitable explant for callogenesis and embryogenesis in the medium. Abu-Romman et al. (2013) used the hypocotyls of cucumber. Our results show the important role of growth regulators including 2,4-D as an auxin, and BA as a cytokinin, which is one of the most important factors in the formation of callus, since the presence of auxin or cytokinin, or both, is essential for the onset of embryogenesis.

The significance and role of these growth regulators in the somatic embryogenesis of cucumber have also been considered by Khalili et al. (2000), Mashayekhi et al. (2012), Elmeer and Hennerty (2008), Von Arnold et al. (2002) which is consistent with the results of this study. The role of 2,4-dichlorophenoxyacetic acid, as an important and constant growth regulator (and often necessary for the induction of embryogenesis), was reported by Cade et al. (1990), Smith (2012) and Ju et al. (2014). Tabassum et al. (2010), pointed to the positive role of two growth regulators, BA and NAA together on somatic embryogenesis. Usman et al. (2011), pointed to the effective role of all three growth regulators, 2,4-D, NAA, and BA. Raju et al. (2013), Cheruvathur et al. (2013), Ugandhar et al. (2011), Alam et al. (2015), referred to the important role of BA growth regulator. Gopi and Ponmurugan (2006), used BA and 2,4-D to obtain embryogenic calli in Ocimum basilicum, which is consistent with our reports on the use of similar regulators. Mamdouh et al. (2014) studied the three varieties of cucumber and produced embryogenic calli from the leaf explants of sterilized seedlings in a basic medium with BA and NAA, which aligns with our research in terms of the type of hormones affecting embryogenesis.

It has often been interpreted that these hormones can change the process of cell division and the onset of asymmetric cell divisions through changing the expression of genes and metabolic changes, leading to the formation of embryoids (Tabassum et al., 2010; Ugandhar et al., 2011; Von Arnold et al., 2002). The results of first and second subcultures of the samples indicate the effective role of sucrose, causing proper osmotic pressure in the medium. This pressure is one of the factors affecting somatic embryogenesis in plants as sucrose is often referred to as a source of organic carbon.

In the first sub culture, the increase of sucrose from $30 \mathrm{mg} / \mathrm{l}$ to $40 \mathrm{mg} / 1$ led to the differentiation of globular embryos into heart-shaped embryos, and in the second sub culture, as the sucrose concentration increased from $30 \mathrm{mg} / \mathrm{L}$ to $50 \mathrm{mg} / \mathrm{L}$, the embryo developmental stages were achieved, and heart-shaped embryos evolved into torpedo-shaped embryos, indicating the role of sugars particularly disaccharides, such as sucrose, in somatic embryogenesis. According to Lou and Kako (1995), Hassanein (2003), the concentration of sucrose was reported to be effective in embryogenesis even without any growth regulator. The osmotic role of sugars and providing proper osmotic pressure, as well as their role as a source of carbon (and a part of the energy needed), could be noted.

The results of ultrasound showed that these waves can affect the formation of embryos, germination of seeds and, to some extent, accelerate the process of flowering. As seen, the control samples and those treated with ultrasound for $10 \mathrm{~min}$ showed better results in terms of embryonic maturity, proper embryonic stages, and subsequently, germination of the seeds compared to the embryos obtained from the calli exposed to waves for a longer time (15 minutes). However, the samples treated for 15 minutes were unable to complete the embryonic development and did not succeed in reaching the embryonic maturity, and the germination of artificial seeds obtained from the somatic embryos was zero, showing a significant difference with the samples treated for 10 minutes, whose results for the formation of embryos, germination and flowering of artificial seeds was the best compared to the control and other treatments.

One of the reasons for this event can be attributed to the heat generated resulting from wave exposure over a longer period of time, affecting the intracellular conditions and can change the process of cell division initiation, causing disorder and deformity in differentiation of callus into embryonic calli. However, there was no significant difference between the control samples and those treated for 10 minutes in the embryonic stages, and most of this difference was observed in the appearance of the embryos. 
On the other hand, it can be deduced that the use of ultrasound waves of the same intensity, but at different time intervals, has different effects, affecting the formation and health of the embryos positively or negatively. According to the results, the average duration (time) can have the best effect on the formation and health of the embryos and, consequently, the germination of the seeds with a higher percentage and accelerated flowering time. Therefore, time (duration) can be considered as a key factor in this regard.

Several researchers have referred to the effective role of ultrasound waves on various aspects of plant tissue culture, including seed germination (Gaba et al., 2008; Rajewska and Mierzwa, 2017). Our results are consistent with the findings of a research conducted by Sharififar et al. (2015), reporting the positive effects of these waves on seed germination of Peganum, Cuminum and Atriplex.

Findings of this study on the positive effects of ultrasound on seed germination are in line with the results presented by Yang et al. (2015), reporting the positive effect of these waves on seed germination of soybean. Hydrogen peroxide formation in the extracellular environment and induction by ultrasound as well as activation of the markers of this path in hazelnut were reported by Ghanati et al. (2015), consistent with our results on the effectiveness of these waves.

In this research, artificial seeds of cucumber were produced using sodium alginate gel according to the Murashige and Skoog (1962), Redenbaugh et al. (1986), Haque and Ghosh (2017) and Tabassum et al. (2010), which were eventually transferred to the greenhouse and turned into plants. The results obtained for the production of artificial seeds and the positive effect of alginates on the maintenance of embryos are consistent with those presented by these researchers. However, as stated in the results, since the somatic embryos obtained from the samples exposed to the waves for a longer time ( 15 minutes) did not complete the maturity stage, there was a significant difference in germination of the seeds compared to the control samples and those treated for 5 and 10 minutes, so that no germination occurred. Moreover, only the seeds in the samples treated for 10 min started the flowering stage.

There are several reports on artificial seed production from somatic embryos, including Das et al. (2016) on Litchi chinensis Sonn; Micheli and Standardi (2016) on citrus trees, Farahani et al. (2015) on apple trees, which are in line with our results on the use of artificial seed technology. The results of artificial seed germination obtained from apical buds showed a significant difference between the samples treated for 15 minutes with those treated for 10 minutes. Also, the treatments were effective in accelerating the flowering time, because the artificial seeds obtained from the samples treated for 10 minutes started the flowering stage faster than the others and within two weeks. This result indicates the positive effects of these waves on the health and maturation of the embryos. The artificial seeds obtained from the control samples started the flowering stage with a delay of two weeks, compared to those treated for 10 minutes. However, the artificial seeds obtained from the samples treated for 5 minutes started the flowering stage very late after eight weeks, and the artificial seeds obtained from the samples treated for 15 minutes did not start the flowering stage at all. Bose et al. (2017) made artificial seeds from the lateral buds of Limonium using sodium alginate and calcium chloride, which eventually turned into plants. This corresponds with our results in terms of using sodium alginate and calcium chloride for artificial seed production.

\section{Conclusions}

Our results clearly showed that average time (duration) (neither long nor short) can have the best effect on the formation and health of the embryos, and consequently higher percentage of seed germination as well as accelerating the flowering stage. So as a novel and simple method, treatment with ultrasound can be used to improvement and accelerate plant's growth and callus induction. Generally, using ultrasound treatment could be a safe technique for agricultural improvements but extensive research is required on different culture media and in different exposure times of samples to ultrasound. 


\section{Authors' Contributions}

MK, performed the experiments, did the sampling, analyses data and wrote the primary draft of the manuscript. AM, and SA, supervised the whole research work and wrote the paper. FG and SJM were advisors and designed some parts of the experiment. All authors read and approved the final manuscript.

\section{Acknowledgements}

This research received no specific grant from any funding agency in the public, commercial, or not-forprofit sectors.

\section{Conflict of Interests}

The authors declare that there are no conflicts of interest related to this article.

\section{References}

Abu-Romman S, Suwwan M, Ezz A (2013). The influence of plant growth regulators on callus induction from hypocotyls of cucumber (Cucumis sativus L.). Advances in Environmental Biology 339-344.

Alam M, Amin R, Uddin M, Biswas S, Islam M (2015). Regeneration of shoot from nodal explants of Cucumis sativus considering different hormonal concentration. International Research Journal of Biological Sciences 4(7):48-52.

Bhatia S, Dahiya R (2015). Concepts and techniques of plant tissue culture science. Modern Applications of Plant Biotechnology in Pharmaceutical Sciences 121-126.

Bose S, Karmakar J, Fulzele DP, Basu U, Bandyopadhyay TK (2017). In vitro shoots from root explant, their encapsulation, storage, plant recovery and genetic fidelity assessment of Limonium hybrid 'Misty Blue': a florist plant. Plant Cell, Tissue Organ Culture 129(2):313-324. https://doi.org/10.1007/s11240-017-1179-6.

Cade RM, Wehner TC, Blazich FA (1990). Somatic embryos derived from cotyledons of cucumber. Journal of the American Society for Horticultural Science 115(4):691-696. https://doi.org/10.21273/JASHS.115.4.691.

Chen B, Huang J, Wang J, Huang L (2008). Ultrasound effects on the antioxidative defense systems of Porphyridium cruentum. Colloids Surf B Biointerfaces 61(1):88-92. https://doi.org/10.1016/j.colsurfb.2007.07.009.

Cheruvathur MK, Kumar GK, Thomas TD (2013). Somatic embryogenesis and synthetic seed production in Rhinacanthus nasutus (L.) Kurz. Plant Cell, Tissue Organ Culture 113(1):63-71. https://doi.org/10.1007/s11240-012-0251-5.

Da Silva JAT, Dobránszki J (2014). Sonication and ultrasound: impact on plant growth and development. Plant Cell, Tissue Organ Culture 117(2):131-143. https://doi.org/10.1007/s11240-014-0429-0.

Das D, Rahman A, Kumari D, Kumari N (2016). Synthetic seed preparation, germination and plantlet regeneration of litchi (Litchi chinensis Sonn.). American Journal of Plant Sciences 7(10):1395. http://dx.doi.org/10.4236/ajps.2016.710133.

Dobránszki J, da Silva JAT (2010). Micropropagation of apple-a review. Biotechnology Advances 28(4):462-488. https://doi.org/10.1016/j.biotechadv.2010.02.008

Duncan DB (1955). Multiple range and multiple F tests. Biometrics 11(1):1-42. https://doi.org/10.2307/3001478

Elmeer KMS, Hennerty MJ (2008). Observations on the combined effects of light, NAA and 2, 4-D on somatic embryogenesis of cucumber (Cucumis sativus) hybrids. Plant Cell, Tissue Organ Culture 95(3):381-384. https://doi.org/10.1007/s11240-008-9439-0.

Gaba V, Kathiravan K, Amutha S, Singer S, Xiaodi X, Ananthakrishnan G (2008). The uses of ultrasound in plant tissue culture. In: Plan Tissue Culture Engineering. Springer, Dordrecht pp 417-426.

https://doi.org/10.1007/978-1-4020-3694-1_22 
Gantait S, Kundu S, Ali N, Sahu NC (2015). Synthetic seed production of medicinal plants: a review on influence of explants, encapsulation agent and matrix. Acta Physiologiae Plantarum, 37(5), 98. https://doi.org/10.1007/s11738-015-1847-2.

George EF (1993). Plant propagation by tissue culture. Part 1: The technology (No. Ed. 2). Exegetics limited.

Ghanati F, Safari M, Hajnorouzi A (2015). Partial clarification of signaling pathway of taxanes increase biosynthesis by low intensity ultrasound treatment in hazel (Corylus avellana) cells. South African Journal of Botany 96:65-70. https://doi.org/10.1016/j.sajb.2014.10.012.

Gopi C, Ponmurugan P (2006). Somatic embryogenesis and plant regeneration from leaf callus of Ocimum basilicum L. Journal of Biotechnol 126(2):260-264. https://doi.org/10.1016/j.jbiotec.2006.04.033.

Haque SM, Ghosh B (2017). Regeneration of Cytologically Stable Plants Through Dedifferentiation, Redifferentiation, and Artificial Seeds in Spathoglottis plicata Blume.(Orchidaceae). Horticultural Plant Journal 3(5):199-208. https://doi.org/10.1016/j.hpj.2017.10.002

Hassanein AM (2003). Somatic embryogenesis of cucumber (Cucumis sativus L) using seed cuttings obtained from premature fruit. Plant Biotechnol (Tsukuba) 20(4):275-281. https://doi.org/10.5511/plantbiotechnology.20.275.

Isah T (2015). Adjustments to in vitro culture conditions and associated anomalies in plants. Acta Biologica Cracoviensia Series Botanica 57(2):9-28. https://doi.org/10.1515/abcsb-2015-0026.

Ju H-J, Jeyakumar J, Kamaraj M, Praveen N, Chung I-M, Kim S-H, Thiruvengadam M (2014). High frequency somatic embryogenesis and plant regeneration from hypocotyl and leaf explants of gherkin (Cucumis anguria L.). Scientia Horticulturae 169:161-168. https://doi.org/10.1016/j.scienta.2014.02.023.

Juturu VN, Mekala GK, Kirti P (2015). Current status of tissue culture and genetic transformation research in cotton (Gossypium spp.). Plant Cell, Tissue Organ Culture 120(3):813-839. https://doi.org/10.1007/s11240-0140640-Z.

Liu Y, Yoshikoshi A, Wang B, Sakanishi A (2003). Influence of ultrasonic stimulation on the growth and proliferation of Oryza sativa Nipponbare callus cells. Colloids Surf B Biointerfaces 27(4):287-293. https://doi.org/10.1016/S0927-7765(02)00052-8.

Lou H, Kako $S$ (1995). Role of high sugar concentrations in inducing somatic embryogenesis from cucumber cotyledons. Scientia Horticulturae 64(1-2):11-20. https://doi.org/10.1016/0304-4238(95)00833-8.

Mamdouh D, Marghany HA, Ewais EA (2014). Assessment of somaclonal variation of calli and regenerated plants of three cucumber (Cucumis sativus L.) cultivars using molecular markers. Report and Opinion 6(12).

Mashayekhi K, Sharifani M, Shahsavand M, Kalati H (2012). Induction of somatic embryogenesis in absence of exogenous auxin in cucumber (Cucumis sativus L.). International Journal of Plant Production 2(2):163-166.

Micheli M, Standardi A (2016). From somatic embryo to synthetic seed in Citrus spp. through the encapsulation technology. In: In Vitro Embryogenesis in Higher Plants, Humana Press, New York pp 515-522. https://doi.org/10.1007/978-1-4939-3061-6_30

Murashige T, Skoog F (1962). A revised medium for rapid growth and bio assays with tobacco tissue cultures. Physiologia Plantarum 15(3):473-497. https://doi.org/10.1111/j.1399-3054.1962.tb08052.x.

Nowacka M, Wedzik M (2016). Effect of ultrasound treatment on microstructure, colour and carotenoid content in fresh and dried carrot tissue. Applied Acoustics 103:163-171. https://doi.org/10.1016/j.apacoust.2015.06.011.

Passalacqua N, Guarrera P, De Fine G (2007). Contribution to the knowledge of the folk plant medicine in Calabria region (Southern Italy). Fitoterapia 78(1):52-68. https://doi.org/10.1016/j.fitote.2006.07.005.

Rajewska K, Mierzwa D (2017). Influence of ultrasound on the microstructure of plant tissue. Innovative Food Science and Emerging Technologies 43:117-129. https://doi.org/10.1016/j.ifset.2017.07.034.

Raju CS, Kathiravan K, Aslam A, Shajahan A (2013). An efficient regeneration system via somatic embryogenesis in mango ginger (Curcuma amada Roxb.). Plant Cell, Tissue Organ Culture 112(3):387-393. https://doi.org/10.1007/s11240-012-0244-4.

Redenbaugh K, Paasch BD, Nichol JW, Kossler ME, Viss PR, Walker KA (1986). Somatic seeds: encapsulation of asexual plant embryos. Nature Biotechnology 4(9):797. https://doi.org/10.1038/nbt0986-797.

Rezaei A, Ghanati F, Behmanesh M, Mokhtari-Dizaji M (2011). Ultrasound-potentiated salicylic acid-induced physiological effects and production of taxol in hazelnut (Corylus avellana L.) cell culture. Ultrasound in Medicine and Biology 37(11):1938-1947. https://doi.org/10.1016/j.ultrasmedbio.2011.06.013.

Safari M, Ghanati F, Behmanesh M, Hajnorouzi A, Nahidian B, Ghahremani M (2013). Enhancement of antioxidant enzymes activity and expression of CAT and PAL genes in hazel (Corylus avellana L.) cells in response to low- 
intensity ultrasound. Acta Physiologiae Planterum 35(9):2847-2855. https://doi.org/10.1007/s11738-013-13186.

Sharififar A, Nazari M, Asghari HR (2015). Effect of ultrasonic waves on seed germination of Atriplex lentiformis, Cuminum cyminum, and Zygophyllum eurypterum. Journal of Applied Research on Medicinal and Aromatic Plants, 2 (3), 102-104. https://doi.org/10.1016/j.jarmap.2015.05.003.

Smith RH (2012). Plant tissue culture: techniques and experiments. Academic Press.

Sunandar A, Supena EDJ (2017). Induction of somatic embryogenesis in sengon (Falcataria moluccana) with thidiazuron and light treatments. HAYATI Journal of Biosciences 24(2):105-108. https://doi.org/10.1016/j.hjb.2017.08.002.

Tabassum B, Nasir IA, Farooq AM, Rehman Z, Latif Z, Husnain T (2010). Viability assessment of in vitro produced synthetic seeds of cucumber. African Journal of Biotechnology 9(42):7026-7032.

Thorpe TA (2007). History of plant tissue culture. Molecular Biotechnology 37(2):169-180. https://doi.org/10.1007/s12033-007-0031-3.

Tripathi L, Tripathi JN (2003). Role of biotechnology in medicinal plants. Tropical Journal of Pharmaceutical Research 2(2):243-253. https://doi.org/10.4314/tipr.v2i2.14607

Ugandhar T, Venkateshwarrlu M, Begum G, Srilatha T, Jaganmohanreddy K (2011). In Vitro plant regeneration of cucumber (Cucumis sativum (L.) from cotyledon and hypocotyl explants. Science Research Reporter 1(3):164169. https://doi.org/10.13140/RG.2.1.4203.3366

Usman M, Hussain Z, Fatima B (2011). Somatic embryogenesis and shoot regeneration induced in cucumber leaves. Pakistan Journal of Botany 43(2):1283-1293.

Vasil IK (2008). A history of plant biotechnology: from the cell theory of Schleiden and Schwann to biotech crops. Plant Cell Reports 27(9):1423. https://doi.org/10.1007/s00299-008-0571-4.

Von Arnold S, Sabala I, Bozhkov P, Dyachok J, Filonova L (2002). Developmental pathways of somatic embryogenesis. Plant Cell, Tissue Organ Culture 69(3):233-249. https://doi.org/10.1023/A:1015673200621.

Yang H, Gao J, Yang A, Chen H (2015). The ultrasound-treated soybean seeds improve edibility and nutritional quality of soybean sprouts. Food Research International 77 704-710. https://doi.org/10.1016/j.foodres.2015.01.011.
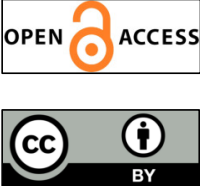

The journal offers free, immediate, and unrestricted access to peer-reviewed research and scholarly work. Users are allowed to read, download, copy, distribute, print, search, or link to the full texts of the articles, or use them for any other lawful purpose, without asking prior permission from the publisher or the author.

License - Articles published in Notulae Botanicae Horti Agrobotanici Cluj-Napoca are Open-Access, distributed under the terms and conditions of the Creative Commons Attribution (CC BY 4.0) License. (c) Articles by the authors; UASVM, Cluj-Napoca, Romania. The journal allows the author(s) to hold the copyright/to retain publishing rights without restriction. 